\title{
Safety of Creatine Supplementation in Active Adolescents and Youth: A Brief Review
}

\author{
Andrew R. Jagim ${ }^{1,2+}$, Richard A. Stecker ${ }^{1}$, Patrick S. Harty ${ }^{1+}$, Jacob L. Erickson ${ }^{2}$ and \\ Chad M. Kerksick ${ }^{\text {1* }}$
}

${ }^{1}$ Exercise and Performance Nutrition Laboratory, Department of Exercise Science, Lindenwood University, St. Charles, MO, United States, ${ }^{2}$ Mayo Clinic Health Systems, Onalaska, WI, United States

Creatine has been extensively researched and is well-supported as one of the most effective dietary supplements available. There is overwhelming support within the literature regarding the ability of creatine to augment performance following short term (5-7 days) and long-duration supplementation periods. There is also strong support for creatine regarding its safety profile and minimal risk for adverse events or any negative

OPEN ACCESS

Edited by: Bruno Gualano,

University of São Paulo, Brazil

Reviewed by:

Scott Forbes,

Brandon University, Canada

Lem W. Taylor

University of Mary Hardin-Baylor,

United States

${ }^{*}$ Correspondence:

Chad M. Kerksick

ckerksick@lindenwood.edu orcid.org/0000-0003-0458-7294

${ }^{\dagger}$ Andrew R. Jagim orcid.org/0000-0002-6651-5096

Patrick S. Harty

orcid.org/0000-0003-0004-2940

Specialty section:

This article was submitted to Sport and Exercise Nutrition,

a section of the journal

Frontiers in Nutrition

Received: 26 September 2018 Accepted: 12 November 2018 Published: 28 November 2018

Citation:

Jagim AR, Stecker RA, Harty PS,

Erickson JL and Kerksick CM (2018) Safety of Creatine Supplementation in Active Adolescents and Youth: A Brief

Review. Front. Nutr. 5:115 doi: 10.3389/fnut.2018.00115 influence on markers of clinical health and safety. Recent research has also highlighted the ability of creatine to confer several health-related benefits in select clinical populations in addition to offering cognitive benefits. Creatine is also a popular supplement of choice for adolescent athletes; however, research in this area is extremely limited, particularly when examining the safety and efficacy of creatine supplementation in this population. Therefore, the purpose of this review was to highlight the limited number of studies available in adolescent populations and systematically discuss the topic of safety of creatine supplementation in a younger population.

Keywords: creatine, safety, adverse events, supplementation, adolescents, youth, performance

\section{INTRODUCTION}

Ergogenic aids are broadly defined as any training technique, mechanical device, nutritional agent or practice, pharmacological method, or psychological technique that can improve exercise performance capacity or enhance training adaptations (1). As a dietary supplement, creatine is regarded as one of the more well-researched and efficacious nutritional ergogenic aids available to athletes (2). When supplemented in the human diet, creatine increases intramuscular creatine stores and can improve exercise capacity and training adaptations. More recently, creatine has been established as a legitimate nutritional adjunct in areas related to rehabilitation and neuromuscular disorders with growing evidence for some therapeutic efficacy in thermoregulation, concussions, head trauma, autism, and neuroprotection (2).

Creatine is a naturally occurring guanidino compound composed of two amino acids (arginine-glycine) found primarily in the flesh of animals, with the majority ( $\sim 95 \%)$ being present in skeletal muscle (2). Approximately two-thirds of intramuscular creatine is phosphocreatine $(\mathrm{PCr})$ while the remaining proportion is free creatine $(\mathrm{Cr})$. Harris et al. (3) demonstrated that a $70-\mathrm{kg}$ individual averages around $120 \mathrm{mM} / \mathrm{kg}$ dry muscle mass of total creatine $(\mathrm{PCr}+\mathrm{Cr}$ ) with an upper limit (after supplementation) of up to $160 \mathrm{mM} / \mathrm{kg}$ dry muscle mass. Ongoing cellular metabolism of creatine results in $1-2 \%$ being degraded, leading to a daily total (exogenous + endogenous) of $1-3 \mathrm{~g}$ of creatine required per day to maintain normal phosphocreatine levels. Depending on food 
tastes and preferences, the human diet commonly provides up to half of this amount with foods such as fish and meats being the main sources with uncooked beef and salmon delivering around 1-2 $\mathrm{g}$ of creatine per pound. The remaining amount of the total rate of appearance is provided by endogenous synthesis by the kidney and liver (2).

\section{Supplementation Regimens and Considerations}

Creatine is stored within skeletal muscle as both free creatine and as phosphocreatine serving as a key substrate for substrate-level phosphorylation and the resynthesis of ATP (4). Collectively, these high-energy phosphates play a vital role in several metabolic processes within the body, particularly during the first $10 \mathrm{~s}$ of high-intensity exercise such that depletion of $\mathrm{PCr}$ is accepted as a major source of fatigue $(5,6)$. Creatine can be found in animal food sources and typically daily ingestion equates to $1-2 \mathrm{~g}$ per day; however $\sim 1-2 \%$ of intramuscular creatine is non-enzymatically metabolized into creatinine daily (2). It is well-supported within the literature that exogenous supplementation of creatine is an effective strategy to increase intramuscular phosphocreatine stores by $20-40 \%$ (2) depending on baseline levels. Commonly, a loading dose of $0.3 \mathrm{~g} / \mathrm{kg}$ of body weight per day for 5-7 days is used as an effective "loading protocol," with a subsequent daily dose of $0.03 \mathrm{~g} / \mathrm{kg}$ of body weight $(3-5 \mathrm{~g} / \mathrm{day})$ required for the maintenance of elevated PCr levels $(3,7,8)$. Alternatively, Hultman et al. (7) demonstrated that a supplementation regimen of $3 \mathrm{~g}$ /day for 28 days can also result in similar levels of intramuscular creatine and phosphocreatine. Finally, once supplementation ceases, studies suggest that it may take as long 4-6 weeks before intramuscular phosphocreatine levels return to baseline $(7,9,10)$. Likely due to the long halflife in muscle, studies have failed to highlight instances where endogenous production is reduced or dampened by previous creatine supplementation after supplementation is stopped. In this respect, it was commonly suggested that creatine users should cycle on and off, but continued evidence suggests that this is not necessary $(11,12)$ particularly when the multitude of benefits resulting from ongoing creatine supplementation are considered.

\section{Safety of Creatine Use}

In adults, a growing number of published randomized controlled trials are available that support the safety of creatine supplementation. These studies have been conducted in both athletic and general populations and range from as short as a few days to as long as 5 years without any adverse changes in markers of clinical health $(12,13)$. Multiple studies have assessed and reported that creatine supplementation has no adverse impact on clinical health markers in competitive athletes (13-17), non-athletic populations (18-25), and in clinical populations (26-29). Furthermore, recent evidence suggests that creatine supplementation is unrelated to the formation of carcinogenic heterocyclic amines in humans, which was a long-standing concern due to creatine's potential role as a precursor of the compounds (30). Generally, the only clinically-relevant side effect of creatine supplementation is weight gain (primarily fat-free mass), which is often a desired outcome in athletes, primarily ones with an emphasis placed on strength, power and body size, and clinical patients with any type of muscle wasting disorders (2). A summary of these studies can be found in Table 1.

\section{Efficacy of Creatine as an Ergogenic Aid}

Use of creatine in athletes can be traced back to the 1990s and since that time, hundreds of papers have been published examining the impact of creatine supplementation on physical performance. In this respect, comprehensive reviews exist on this topic and the interested reader is encouraged to read them (2, 36-39). However, it is beyond the scope of this current review to discuss this literature in detail. Briefly, several studies have indicated that supplementation periods as short as 3-5 days are sufficient to confer an ergogenic benefit with improvements in exercise capacity, anaerobic capacity, power, and sport-specific tasks consistently being observed $(36,40)$. When supplementation stretches to several weeks, augmented training adaptations such as greater improvements in strength, lean body mass and anaerobic performance, when used in conjunction with a structured training program, are commonly reported (2, 37, 41-43). Finally, and as summarized by Kreider et al. (2), these outcomes are consistently reported across genders as well as in adolescents (44-48), younger adults $(32,49-59)$ and older individuals (38, 41, 60-68). Table 2 highlights many examples of sporting events that may be enhanced by creatine supplementation. As an ergogenic aid and in summary, creatine supplementation is commonly one of the most highly recommended and advocated by researchers and professional organizations $(1,2,79)$.

\section{PREVALENCE OF CREATINE USE IN ADOLESCENTS}

A key question to answer relative to the premise of this paper is, "Are adolescent athletes using creatine?" In this respect, the use of dietary supplements to enhance performance or health is not limited to adult populations and is an increasingly popular strategy among young, active individuals (80), as outlined in Table 3. When surveyed, $\sim 5-20 \%$ of middle school and high school aged individuals reported taking creatine at some point. For example, Metzl and associates (70) surveyed 1,103 US girls and boys in grades $6-12$ and reported that $8.8 \%$ of boys and $1.8 \%$ of girls reported supplementing with creatine. Interestingly, creatine use was consistent at $3.4 \%$ in grades $6-10$ while substantially increasing to 12 and $44 \%$ use in grades 11 and 12 , respectively. Similarly, Kayton et al. (71) surveyed 270 US high school students $13-18$ years of age and found that $21 \%$ of boys and $3 \%$ of girls reported using creatine. When prevalence rates among adolescent athletes are evaluated, similar trends emerge as creatine is often listed as one of the more commonly used dietary supplements among this population $(76,81)$. Regardless, there does still appear to be variability in prevalence rates, which 


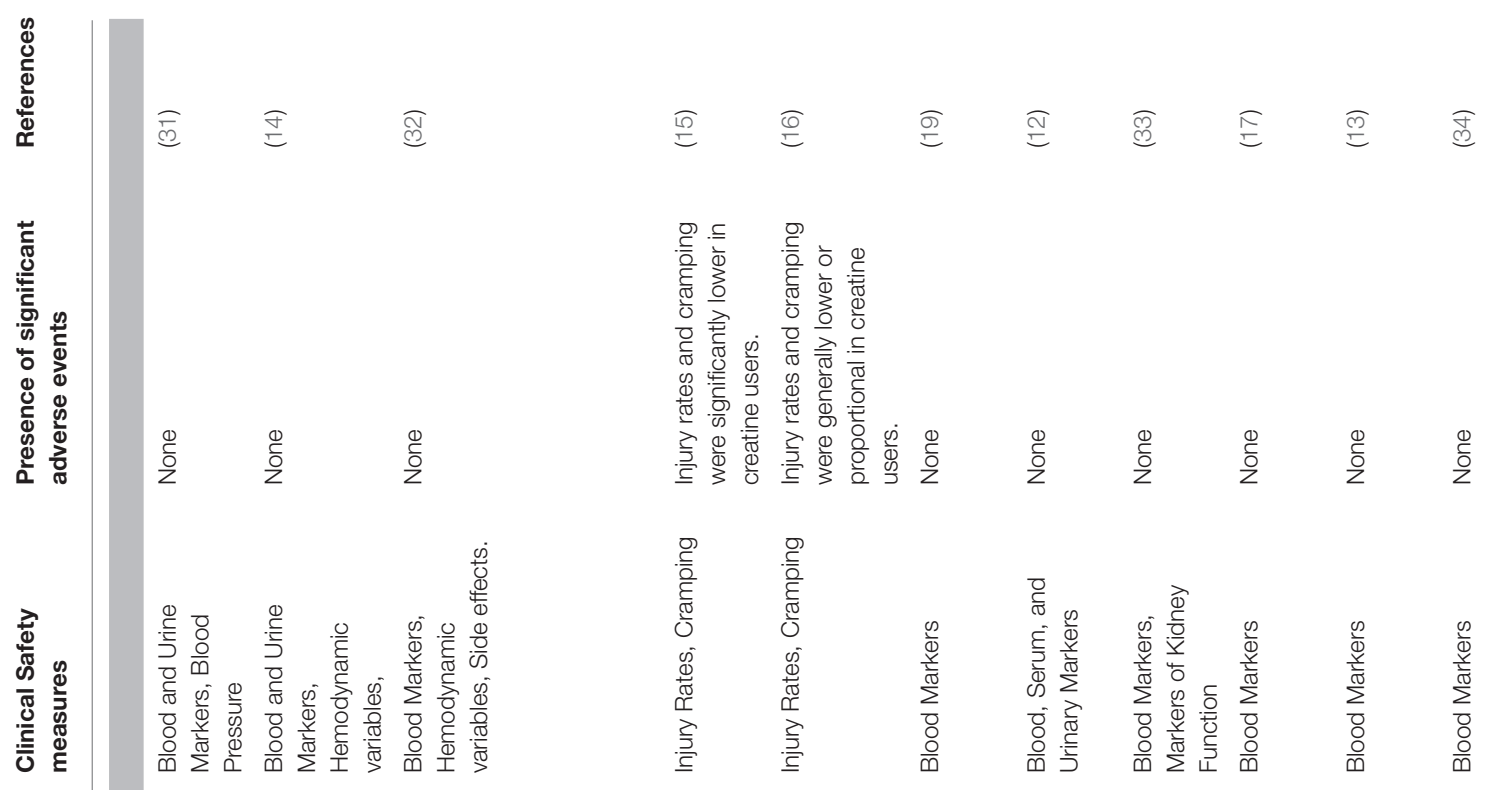

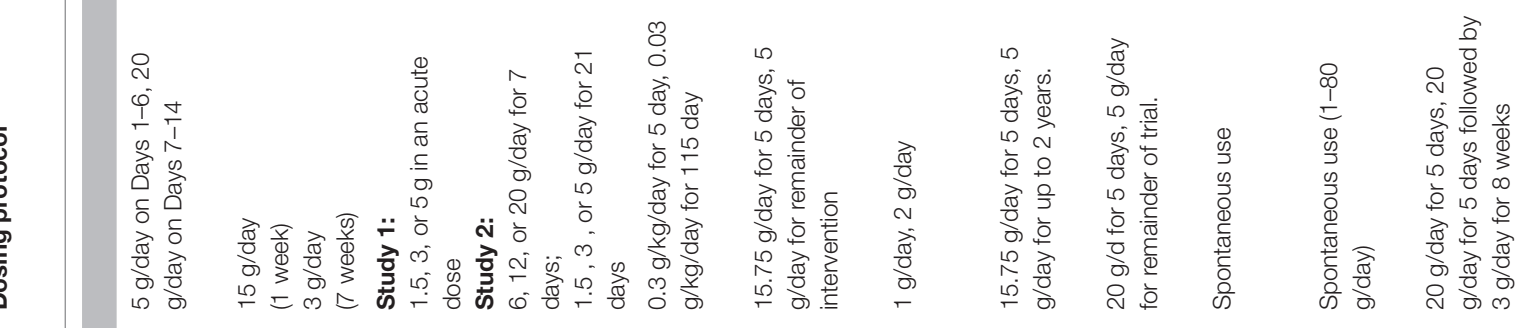

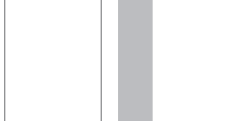




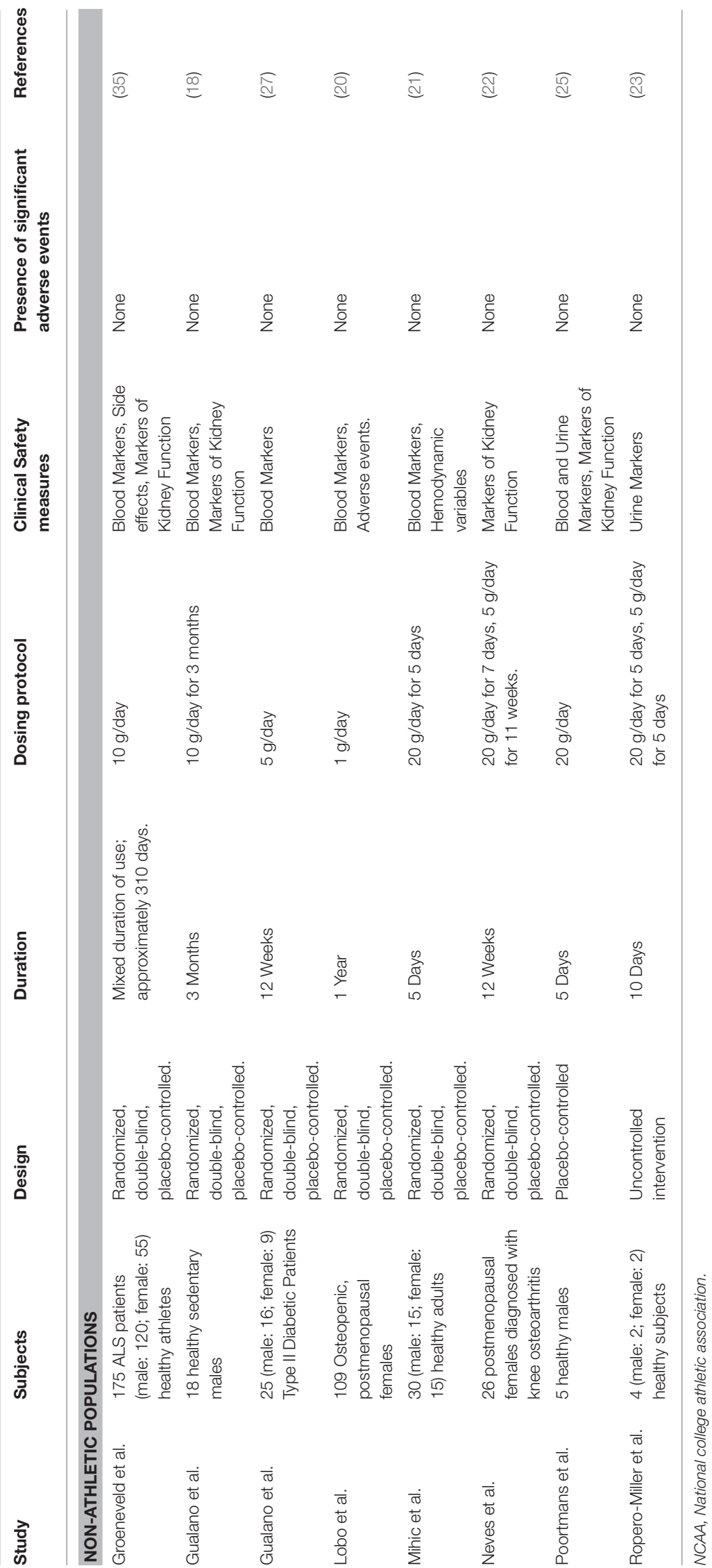


TABLE 2 | Dietary supplement use in youth and adolescent populations.

\begin{tabular}{|c|c|c|}
\hline References & Population & Key findings \\
\hline $\begin{array}{l}\text { Smith and Dahm } \\
\text { (69) }\end{array}$ & U.S. High Schools & $\begin{array}{l}\text { Population: } 328 \text { students (55\% boys, } 45 \% \text { girls, } 15.2 \pm 1.3 \text { years) } \\
\text { Usage Statistics: Creatine use of } 8.2 \% \text { ( } 26 \text { boys, } 1 \text { girl) } \\
\text { Sports: Football (29\%), soccer and hockey } \\
\text { Perceived Efficacy: } 79 \% \text { felt it improved their performance } \\
\text { Frequency: } 35 \% \text { daily, 35\% weekly, 30\% rate usage } \\
\text { Dosing: } 55 \% \text { could not recall dosage, } 23 \% \text { ( } 5 \mathrm{~g} / \text { day), } 23 \% \text { (5-10 g/day) } \\
\text { Primary Information Source: Friends }\end{array}$ \\
\hline Metzl et al. (70) & U.S. - Middle and High School & $\begin{array}{l}\text { Population: } 1,103 \text { (55\% boys, } 45 \% \text { girls, Grades } 6-12) \\
\text { Usage Statistics: Creatine use ( } 8.8 \% \text { boys, } 1.8 \% \text { girls). Creatine use was stable (3.4\%) from grades } 6-\text {, } \\
12 \% \text { use in } 11 \text { th grade and } 44 \% \text { use in } 12 \text { th grade. } \\
\text { Sports: Strength and power sports (football, wrestling, hockey) } \\
\text { Reasons to Take: Improve performance }(72 \%) \text {, Improve appearance }(61 \%) \text {, and improve speed }(40 \%) \\
\text { Reasons Not Taking: Safety concerns (46\%), lack of perceived benefit }(20 \%) \text {, expense }(13 \%)\end{array}$ \\
\hline Kayton et al. (71) & U.S. - High School & $\begin{array}{l}\text { Population: } 270 \text { athletic high school boys (45\%) and girls (55\%), } 13-18 \text { years } \\
\text { Usage Statistics: Sports drinks were most common (59\%), vitamin/minerals (46\%), creatine (21\% in } \\
\text { boys, } 3 \% \text { in girls), amino acids ( } 8 \% \text { in boys, } 1 \% \text { girls) } \\
\text { Reasons to Take: Gain muscle, increase energy, prevent illness } \\
\text { Primary Information Source: Coaches, doctors and parents were primary sources of nutrition and dietary } \\
\text { supplement information, parents have largest influence on use. }\end{array}$ \\
\hline O’Dea (72) & Australia-Middle \& High School & $\begin{array}{l}\text { Population: } 78 \text { students, grades } 7-11,11-18 \text { years } \\
\text { Usage Statistics: Sports drink ( } 56 \%) \text {, vitamin/minerals ( } 49 \%) \text {, energy drinks }(42 \%) \text {, creatine }(5 \%) \text {, protein } \\
\text { supplements (4\%). Creatine was taken only by boys, all others were consumed by both gender. } \\
\text { Reasons for Taking: Energy production or boost } \\
\text { Misc.: Athletes had little to no knowledge of adverse events }\end{array}$ \\
\hline Bell et al. (73) & Canada-High School & $\begin{array}{l}\text { Population: } 333 \text { high school boys }(57 \%) \text { and girls }(42 \%), 15.4 \pm 1.1 \text { years } \\
\text { Usage Statistics: Vitamin/minerals (43\%), protein (14\%), creatine (5.3\%). Boys reported similar use of } \\
\text { vitamin/minerals as girls, greater protein and creatine use when compared to girls } \\
\text { Reasons for Taking: Students taking protein (43\%) and creatine (42\%) believed it would help their } \\
\text { performance }\end{array}$ \\
\hline Hoffman et al. (74) & U.S. - High School & $\begin{array}{l}\text { Population: 3,248 students in grades } 8-12 \\
\text { Usage Statistics: Vitamin/minerals (59\%), energy drinks (32\%), protein (15\%), and creatine (7\%). Boys } \\
\text { reported greater use of energy drinks, protein and creatine with progressively higher levels of protein } \\
\text { ( } 40 \% \text { of } 12 \text { th grade boys) and creatine ( } 22 \% \text { of } 12 \text { th grade boys) use occurring with age. } \\
\text { Primary Information Source: Teachers (36\%) and parents (16\%). As grade levels increased, parents, } \\
\text { friends, coaches, athletic trainers, and internet sites take on larger roles }\end{array}$ \\
\hline $\begin{array}{l}\text { Petroczi and } \\
\text { Naughton (75) }\end{array}$ & U.K. - Young Elite Athletes & $\begin{array}{l}\text { Population: } 403 \text { elite athletes (12-21 years, } 17.7 \pm 2.0 \text { years) } \\
\text { Usage Statistics: Energy drinks ( } 87 \%) \text {, vitamin/minerals (47\%), whey protein (44\%), and creatine (28\%) } \\
\text { Sports: Rugby, soccer and swimming } \\
\text { Misc.: Large majority (78\%) did not believe nutritional supplementation was needed to achieve success } \\
\text { in sports }\end{array}$ \\
\hline Diehl et al. (76) & Germany-Young Elite Athletes & $\begin{array}{l}\text { Population: 1,138 Olympic level competitors (14-18 years, 56\% boys, 44\% girls) } \\
\text { Usage Statistics: Vitamin/minerals (34-69\%), energy drinks (64\%), protein (38\%), creatine (12\%) }\end{array}$ \\
\hline Evans et al. (77) & U.S. - Youth & $\begin{array}{l}\text { Population: } 73.7 \text { million U.S. children (10.8 } \pm 0.2 \text { years, } 57 \% \text { older than age of } 10) \\
\text { Usage Statistics: } 1.64 \% \text { ( } 1.2 \text { million) used some form of supplement to enhance sport performance in } \\
\text { last } 30 \text { days. } 94.5 \% \text { used vitamin/minerals, } 44 \% \text { used fish oils, } 34 \% \text { used creatine, } 26 \% \text { used fiber. } \\
\text { Misc.: Boys were } 2 x \text { as likely to use something. Independent of gender, usage increased with age ( } 47 \% \\
\text { of } 9-12 \text { graders) }\end{array}$ \\
\hline
\end{tabular}

Adapted from Kerksick and Fox (78).

is likely attributable to differences in gender, sport-type and associated body composition or training-related goals (70, 75, $76,82,83)$. Males appear to be more likely than females to report using creatine and the most commonly reported reasons for supplementation often include a desire to increase lean body mass and for increased energy production. As a result, strength and power or anaerobic-type sports such as football, wrestling, and hockey appear to have the highest rates of use. For example, McGuine et al. (81) reported that $16.7 \%$ of 4,000 surveyed high school athletes reported using creatine, with prevalence rates as high as $30.1 \%$ in football players and as low as $1.3 \%$ in female cross-country runners. In a similar study, Smith and Dahm (69) reported $8.2 \%$ of surveyed high school athletes reporting taking creatine, though reported use was as high as $21 \%$ in all football players surveyed. These prevalence rates certainly highlight the fact that creatine is a popular dietary supplement choice of adolescents, highlighting the need for more research in this area. 
TABLE 3 | Sports and sporting events where performance may be enhanced by creatine supplementation.

\author{
Increased PCr \\ - Track sprints: 60-200m \\ - Swim sprints: $50 \mathrm{~m}$ \\ - Pursuit cycling \\ Increased PCr Resynthesis \\ - Basketball \\ - Field Hockey \\ - American Football \\ - Ice Hockey \\ - Lacrosse \\ - Volleyball \\ Reduced Muscle Acidosis \\ - Downhill skiing \\ - Water sports (e.g., Rowing, Canoe, Kayak, Stand-Up Paddling) \\ - Swim events: $100,200 \mathrm{~m}$ \\ - Track events: 400, 800 m \\ - Combat Sports (e.g., MMA, Wrestling, Boxing, etc.) \\ Oxidative Metabolism \\ - Basketball \\ - Soccer \\ - Team Handball \\ - Tennis \\ - Volleyball \\ - Interval training in endurance athletes \\ Increased Body Mass/Muscle Mass \\ - American Football \\ - Bodybuilding \\ - Combat Sports (e.g., MMA, Wrestling, Boxing, etc.) \\ - Powerlifting \\ - Rugby \\ - Track/Field events (Shot put; javelin; discus; hammer throw) \\ - Olympic Weightlifting
}

MMA, Mixed martial arts; PCr, Phosphocreatine.

Reproduced from Kreider et al. (2) under the terms of the Creative Commons Attribution 4.0 International License (http://creativecommons.org/licenses/by/4.0/).

\section{REVIEW METHODOLOGY}

To illustrate the paucity of literature directly examining the safety of creatine supplementation in youth, a systematic review was performed in accordance with the Preferred Reporting Items for Systematic Reviews and Meta-analyses (PRISMA) guidelines (Figure 1). PubMed, MEDLINE, and SportDiscus databases were each searched using the following terms: "creatine supplementation" AND "safety" AND "humans" AND "adolescents." A second search was conducted using the terms "creatine supplementation" AND "safety" AND "humans" AND "youth." The final search and accession date using these parameters was 08/31/2018.

Studies were eligible for inclusion if they met all of the following criteria: (1) original research conducted in humans under 18 years of age; (2) published in peer-reviewed academic journals; (3) implemented an intervention of at least 3 days using creatine only; (4) reported a clinical measure of safety as a primary outcome measure; (5) recruited populations that were not receiving creatine as a treatment for any diagnosed medical condition; (6) utilized a double-blind, placebo-controlled design. Two independent reviewers $(\mathrm{CK}$ and $\mathrm{PH})$ assessed all articles to determine eligibility. For the purpose of this review, we have used the terms "youth" in reference to individuals between 7-12 years of age and "adolescent" for those between 13-18 years of age.

\section{CREATINE USE IN YOUTH}

As illustrated, the number of published studies that have been completed in youth or adolescent populations is quite small ( $n$ $=8$ ), particularly when compared to the number of studies in adults. All of the studies outlined in Table $\mathbf{4}$ used an adolescent participant and sought to examine some aspect of efficacy of creatine use in reference to sporting performance. Further, as can be seen from our PRISMA diagram (Figure 1), no published studies to date have been completed with a priori intent to examine the safety of creatine use in adolescents and youth. For these reasons, we have chosen to first discuss the efficacy studies available in adolescent populations before attempting to ascertain as much information as possible about the safety of creatine use in young populations.

\section{Efficacy of Creatine Use in Adolescents}

Despite the overwhelming supportive body of literature regarding the efficacy of creatine supplementation in adult athletes, limited data are available in adolescent athletes. This lack of available literature is likely attributable to ethical restrictions, safety concerns and methodological challenges. With that being said, Unnithan et al. (88) eloquently described the physiological basis for creatine use in adolescents and came to the conclusion that in anaerobic athletes, there exists a metabolic rationale as to how and why creatine may provide an ergogenic benefit. Additionally, in a 2017 position stand published by the International Society of Sports Nutrition (2), it was recommended that "younger athletes should consider a creatine supplement if the following conditions are met..." and then went on to describe certain criteria surrounding approval from parents, choosing quality supplements, abiding by recommended dosing instructions and optimizing diet prior to supplementation. However, recent evidence suggests that exogenous creatine supplementation may be less effective in children and adolescents compared to adults due to limited tissue creatine uptake, particularly in brain tissues $(89,90)$.

Grindstaff et al. (46) were one of the first groups to examine the effects of creatine supplementation on performance in adolescent athletes. For the study, 18 male and female swimmers (15.3 \pm 0.6 years) were randomly assigned to one of two groups to ingest either $21 \mathrm{~g}$ /day of creatine or placebo over a period of 9 days. The researchers noted significant improvements in repeat sprint performance in swimmers after creatine supplementation. Shortly after, Dawson et al. (45) tried to replicate these findings in young, elite swimmers $(16.4 \pm 1.8$ years $)$ using an extended creatine supplementation period of 28 days. The authors did not observe any significant improvement in single sprint performance following 4 weeks of creatine supplementation (20 $\mathrm{g} /$ day for 5 days; followed by $5 \mathrm{~g}$ /day for 22 days) but did note a significant improvement in swim bench test performance. Later in 2004, Ostojic et al. (85) observed significant improvements in 


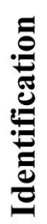

递

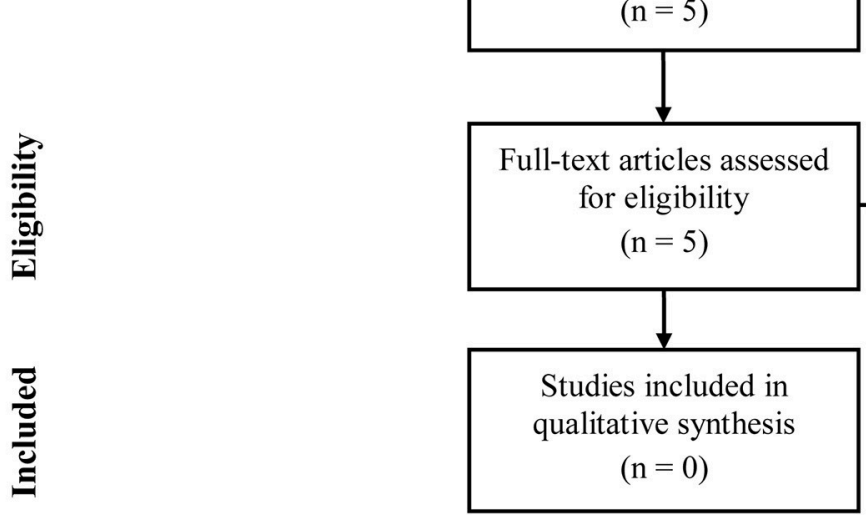

Records identified through database searching $(n=46)$

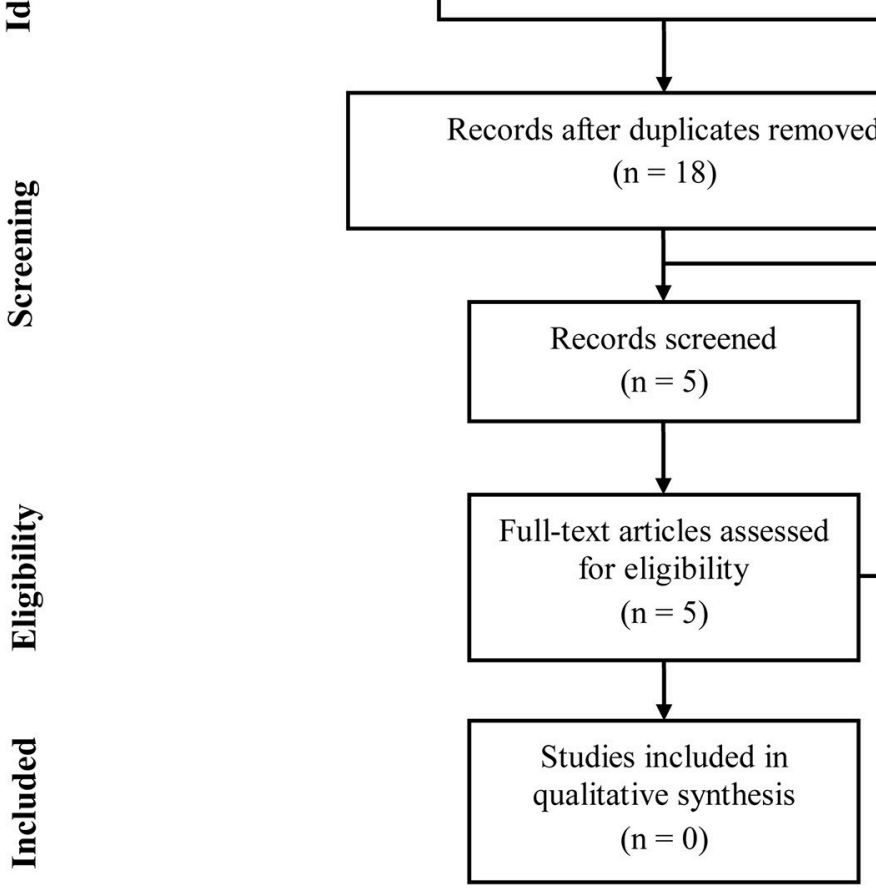

Records excluded $(n=13)$

-Review Articles

-Irrelevant study populations

-Irrelevant nutritional interventions

-No nutritional intervention

-Retrospective design
Full-text articles excluded, with reasons $(n=5)$

-Study population older than $18 \mathrm{y}$

-Creatine given as part of a blend of supplements

FIGURE 1 | PRISMA flow chart.

soccer-specific skills following 7 days of creatine supplementation (30 g/day) in 20 young (16.6 \pm 1.9 years), male soccer players. Juhasz et al. (47) examined the effects of 5 days of creatine supplementation $(4 \times 5 \mathrm{~g} /$ day $)$ on mechanical power output and swim performance in highly trained junior (15.9 \pm 1.6 years) competitive swimmers. The researchers observed significant improvements in sprint swimming performance and dynamic strength following creatine supplementation. Mohebbi et al. (84) also examined the effects of creatine supplementation ( $20 \mathrm{~g} /$ day) on repeat sprint performance, dribbling and shooting accuracy in 17 young (17.2 \pm 0.1 years), soccer players. Following 7 days of supplementation, significant improvements in repeat sprint performance and dribbling abilities were observed. Most recently, in 2017 a similar study (86) with elite youth (17.0 \pm 0.5 years) soccer players found significant improvements in power output following a low-dose creatine supplementation regimen $(0.03 \mathrm{~g} / \mathrm{kg} /$ day $)$ for 7 days. In three of the eight studies mentioned, no adverse events or side-effects were reported by the participants following supplementation, and the remaining five studies did not report adverse event occurrences. Although not an extensive list, a precedent has been set regarding creatine supplementation interventions in adolescent athletes, warranting further research in this area examining both efficacy and safety. Table 4 outlines relevant details of these studies.

\section{Is Creatine Safe for Youth?}

As can be seen in Figure 1, the results of our systematic review revealed that no studies to date have been completed that sought to directly examine the safety of creatine use in an adolescent or youth population. Subsequently, each efficacy study in adolescents (Table 4) was closely reviewed by the authors to ascertain any information that might be present regarding any clinical side effects resulting from creatine use in adolescents. In this respect, none of these studies observed any gastrointestinal discomfort or changes in hemodynamic, urine, or any blood markers of clinical health and safety following the supplementation periods.

What is important to highlight is that several studies are available that have used creatine supplementation in children as some form of a medical therapy. The most common application of creatine in clinical pediatric populations involve children born with one form of a creatine deficiency syndrome. This class of syndromes results in a reduction or inability to endogenously synthesize creatine leading low levels of creatine and phosphocreatine in the muscle and brain. The physical presentation of this scenario includes muscle myopathies, gyrate atrophy, movement disorders, speech delay, autism, mental development challenges, epilepsy, and other developmental problems (91-93), as reviewed by Kreider et al. (2). Similarly, Battini et al. (94) reported on a child born with a creatine 


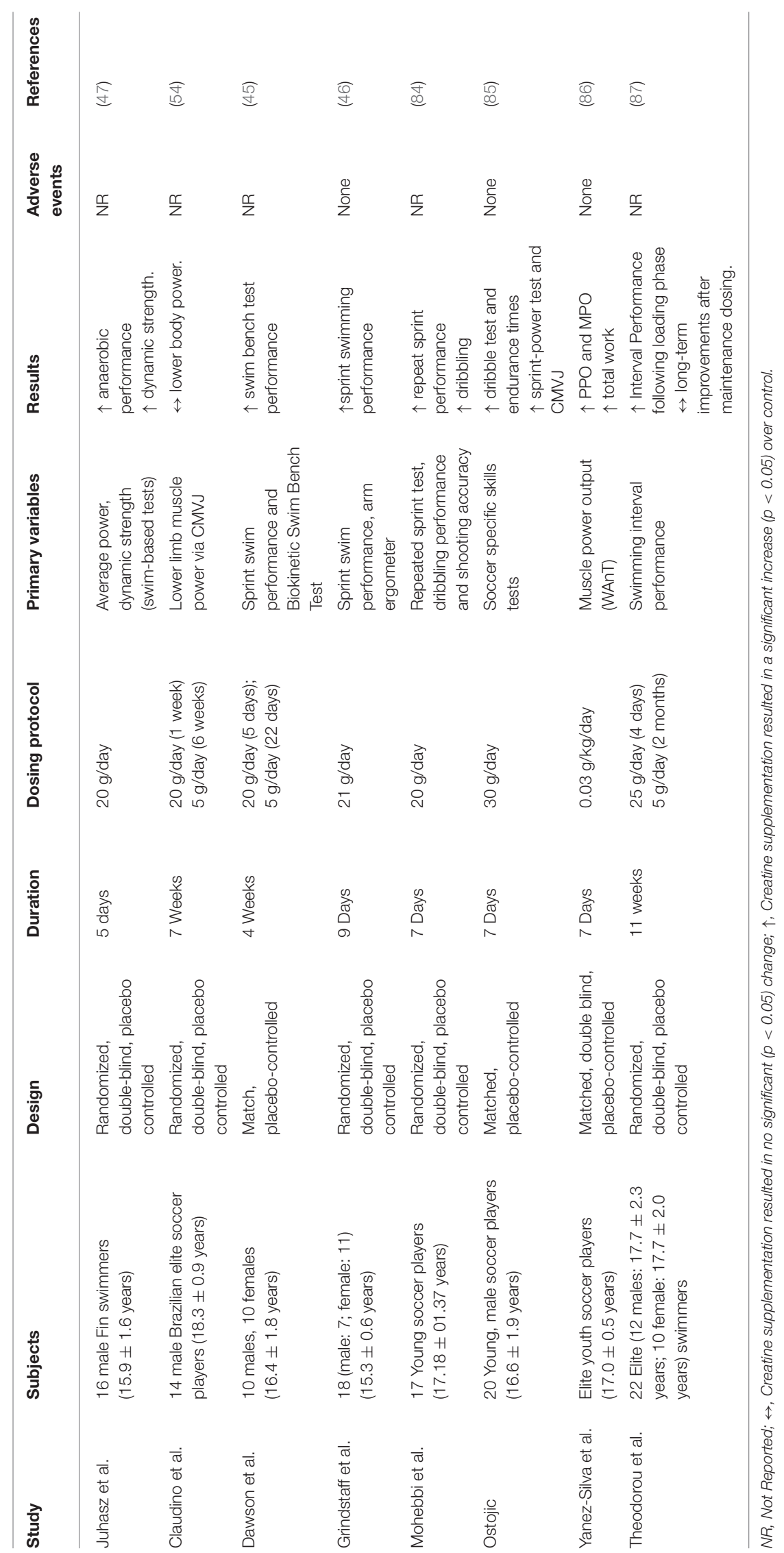


deficiency syndrome who, at 4 months of age, was treated with creatine supplementation. Moreover, Stocker-Ipsiroglu et al. (95) administered creatine monohydrate $(0.3-0.8 \mathrm{~g} / \mathrm{kg} /$ day, equivalent to $13.5-62 \mathrm{~g}$ of creatine per day for an individual weighing $45-77 \mathrm{~kg}$ [100-160 pounds]) to patients ranging from 25.5 months to 11 years (median age: 51 months) for a treatment period of 11-192 months (median treatment duration: 48 months). The researchers found that creatine supplementation increased brain creatine levels and stabilized other clinical outcomes. Creatine supplementation is also commonly used as a therapeutic agent for improving musculoskeletal function in patients suffering from muscular dystrophy (96-98). Most notable is a creatine supplementation study by Tarnopolsky et al. (96) who observed significant improvements in fat-free mass and handgrip strength after 4 months of creatine monohydrate supplementation $(0.10 \mathrm{~g} / \mathrm{kg} /$ day) in 30 young boys (mean age: $10 \pm 3$ years) with Duchenne muscular dystrophy. Similarly, Hayashi et al. (99) administered $0.1 \mathrm{~g} / \mathrm{kg}$ creatine per day for 12 weeks to patients with childhood systemic lupus erythematosus and detected no deleterious changes in laboratory parameters of inflammation, hematology, skeletal muscle enzymes, or kidney and liver function. Creatine supplementation has also been shown to be an effective therapy to treat gyrate atrophy of the retina. Vannas-Sulonen et al. (29)reported on 13 patients who ranged in age from 6 to 31 years old. In particular, five patients were $<18$ years of age (6-16 years, median: 12 years; $119-174 \mathrm{~cm}$, median: $165 \mathrm{~cm}, 21-76 \mathrm{~kg}$, median: $56 \mathrm{~kg}$ ) and were treated with creatine for 40-72 months, median treatment duration: 60 months).

It is worth mentioning that some individuals point to the warnings provided on product labels that individuals younger than 18 years of age should not take creatine and inappropriately extrapolate this as evidence that creatine supplementation is unsafe in younger populations, rather than acknowledging there are insufficient data to confirm the need for such warnings. These warnings are not scientifically-based and are provided more as a legal precaution. Regardless, the point remains that no published studies are available to date that have used a rigorous study design to examine the impact of creatine supplementation on markers of health and safety in healthy populations, specifically athletes.

\section{A Balanced Perspective}

Despite the overwhelming body of evidence supporting the safety and efficacy of creatine supplementation in adult athletes, there still exists a plethora of misconceptions and concerns regarding the use of creatine in adolescents that are not wellsubstantiated within the literature. Commonly, conversations that start with discussions of proper fueling and hydration can transition into unsubstantiated statements surrounding the purported safety of creatine use in a younger population, often associating creatine with illegal performance-enhancing drugs. For example, Greydanus and Patel (100) assessed the incidence of sports doping in adolescents and included creatine as an "anabolic-like agent" when describing anabolic steroid use. As another example, Ranby et al. (101) included creatine with anabolic steroids in the same category when describing changes in a survey designed to determine the intention or knowledge of using performance enhancing substances. These situations are troubling because first, creatine is not a steroid nor does it act like one, as it has a completely different molecular structure and physiological mechanism of action; and second, these unsubstantiated comments cloud the ability of individuals to understand key evidence-based information that exists on creatine while also instilling complications with the research process regarding adolescents. Furthermore, the toxicity from anabolic steroids are well-documented and inappropriately discussing creatine within this category implies "guilt by association."

It is important to acknowledge that a seemingly large proportion of adolescent athletes are using or have tried creatine (see previous sections). Furthermore, it is also worth noting that creatine is not banned by any major athletic governing body or organization. While these facts are not to be intended as an endorsement of its use in young athletes, they further solidify the need for scientifically controlled investigations that seek to determine the safety of creatine use in adolescents.

\section{CONCLUSIONS}

A major driving force of this article is to clearly focus upon the available scientific information involving creatine supplementation in youth and adolescent populations. A significant amount of concern and caution have been present within the media and sporting world up to this point regarding creatine use in younger populations. Even within the scientific literature creatine supplementation in adolescents has inappropriately been classified as "unhealthy behavior" (101), "disturbing trends" (70), or has been compared to illegal performance enhancing drug use (100) without any supporting evidence of its dangers or scientific rationale for such a classification. Unfortunately, such concern at times has resulted in multiple scenarios where dramatized accounts of creatine's impact or its associations next to other anabolic agents are made that are at best, inappropriate, and at worst, unethical. Evidence continues to accumulate; however, that clearly highlights the fact that high school-aged individuals and younger are using creatine. While prevalence statistics of creatine use in youth do not warrant an endorsement by anyone, the lack of consistent medical reports involving clinically compromising situations in combination with years of medical applications of creatine in children with inborn errors of metabolism or neurological diseases certainly opens the door for people to understand that creatine supplementation in healthy adolescent populations has the potential to be well-tolerated with little incident. Furthermore, an emerging body of literature in adolescent athletes using creatine has suggested that, first, creatine use in adolescent athletes appears to be well-tolerated with no reported adverse events and, second, that creatine use in this population can operate in an ergogenic fashion [see Table 4, also extensively reviewed by (2)]. Finally, one should not dismiss the now $25+$ years of research that continues to highlight that creatine use in a multitude of populations is safe and effective means to improve both clinical and ergogenic outcomes (1). 
It is our sincere hope that this article will serve as a guide for other researchers, Institutional Review Boards (IRBs), clinicians, professional organizations, and governing bodies to use when determining the safety and efficacy of creatine use in youth and adolescent populations. In this respect and in completing this review, we have identified areas where scientifically controlled, high-quality studies are needed to help build and progress this body of literature. Most importantly, short-term ( $<7$ days) and long-term (weeks to months) studies that employ well-powered, randomized, double-blind, placebocontrolled study designs are desperately needed to examine the impact of creatine supplementation on traditional markers of clinical safety (hemodynamic changes, urine parameters, complete blood counts, and comprehensive metabolic and lipid panels) after acute and prolonged creatine supplementation regimens in adolescent populations. Therefore, this review may lend itself as a call to action for future work in this area by providing a comprehensive summary of the relevant literature and identifying the need to assess the clinical safety of creatine supplementation within this population. Such work is of paramount importance, as it will begin to demonstrate the safety of creatine use in adolescent populations under scientifically controlled conditions. From there, studies that examine the minimum effective dose of creatine or any prudent modifications

\section{REFERENCES}

1. Kerksick CM, Wilborn CD, Roberts MD, Smith-Ryan A, Kleiner $\mathrm{SM}$, Jager R, et al. ISSN exercise \& sports nutrition review update: research \& recommendations. J Int Soc Sports Nutr. (2018) 15:38. doi: 10.1186/s12970-018-0242-y

2. Kreider RB, Kalman DS, Antonio J, Ziegenfuss TN, Wildman R, Collins $\mathrm{R}$, et al. International society of sports nutrition position stand: safety and efficacy of creatine supplementation in exercise, sport, and medicine. J Int Soc Sports Nutr. (2017) 14:18. doi: 10.1186/s12970-0170173-z

3. Harris RC, Soderlund K, Hultman E. Elevation of creatine in resting and exercised muscle of normal subjects by creatine supplementation. Clin Sci. (1992) 83:367-74

4. Jager R, Purpura M, Shao A, Inoue T, Kreider RB. Analysis of the efficacy, safety, and regulatory status of novel forms of creatine. Amino Acids (2011) 40:1369-83. doi: 10.1007/s00726-011-0874-6

5. Gastin PB. Energy system interaction and relative contribution during maximal exercise. Sports Med. (2001) 31:725-41. doi: 10.2165/00007256-200131100-00003

6. Allen DG, Lamb GD, Westerblad H. Skeletal muscle fatigue: cellular mechanisms. Physiol Rev. (2008) 88:287-332. doi: 10.1152/physrev.00015.2007

7. Hultman E, Soderlund K, Timmons JA, Cederblad G, Greenhaff PL. Muscle creatine loading in men. J Appl Physiol. (1996) 81:232-7.

8. Mesa JL, Ruiz JR, Gonzalez-Gross MM, Gutierrez Sainz A, Castillo Garzon MJ. Oral creatine supplementation and skeletal muscle metabolism in physical exercise. Sports Med. (2002) 32:903-44. doi: 10.2165/00007256-200232140-00003

9. Greenhaff PL, Casey A, Short AH, Harris R, Soderlund K, Hultman E. Influence of oral creatine supplementation of muscle torque during repeated bouts of maximal voluntary exercise in man. Clin Sci. (1993) 84:565-71.

10. Vandenberghe K, Goris M, Van Hecke P, Van Leemputte M, Vangerven L, Hespel P. Long-term creatine intake is beneficial to muscle performance during resistance training. J Appl Physiol. (1997) 83:2055-63. to the regimens of creatine supplementation that are discussed in this article and elsewhere should be undertaken. In this respect, creatine turnover in the adult is known (and was briefly discussed), but when one considers the eating patterns of children and how creatine turnover may differ in this population, the need to explore relevant dosing amounts and patterns is also important.

\section{AUTHOR CONTRIBUTIONS}

AJ and CK conceptualized the topic of this review. AJ, RS, PH, JE, and CK researched and analyzed the literature and assisted in manuscript preparation. JE provided scholarly guidance on the topic, assisted in manuscript preparation, and revised the manuscript critically. PH and CK performed the systematic review. All authors contributed to manuscript revision, have read, and approve of the final version of the manuscript.

\section{ACKNOWLEDGMENTS}

We would like to thank and recognize Mark Tarnopolsky, MD, Ph.D., of McMaster University for critically reviewing and offering valuable insight regarding the direction and interpretation of this manuscript.

11. Kim HJ, Kim CK, Carpentier A, Poortmans JR. Studies on the safety of creatine supplementation. Amino acids (2011) 40:1409-18. doi: 10.1007/s00726-011-0878-2

12. Kreider RB, Melton C, Rasmussen CJ, Greenwood M, Lancaster S, Cantler EC, et al. Long-term creatine supplementation does not significantly affect clinical markers of health in athletes. Mol Cell Biochem. (2003) 244:95-104. doi: 10.1023/A:1022469320296

13. Poortmans JR, Francaux M. Long-term oral creatine supplementation does not impair renal function in healthy athletes. Med Sci Sports Exer. (1999) 31:1108-10

14. Cancela P, Ohanian C, Cuitino E, Hackney A. Creatine supplementation does not affect clinical health markers in football players. Br J Sports Med. (2008) 429:731-5. doi: 10.1136/bjsm.2007.030700

15. Greenwood M, Kreider RB, Greenwood L, Byars A. Cramping and injury incidence in collegiate football players are reduced by creatine supplementation. J Athlet Train. (2003) 38:216-9.

16. Greenwood M, Kreider RB, Melton C, Rasmussen C, Lancaster S, Cantler $\mathrm{E}$, et al. Creatine supplementation during college football training does not increase the incidence of cramping or injury. Mol Cell Biochem. (2003) 244:83-8. doi: 10.1023/A:1022413202549

17. Mayhew DL, Mayhew JL, Ware JS. Effects of long-term creatine supplementation on liver and kidney functions in American college football players. Int J Sport Nutr Exerc Metab. (2002) 12:453-60. doi: 10.1123/ijsnem.12.4.453

18. Gualano B, Ugrinowitsch C, Novaes RB, Artioli GG, Shimizu MH, Seguro AC, et al. Effects of creatine supplementation on renal function: a randomized, double-blind, placebo-controlled clinical trial. Eur J Appl Physiol. (2008) 103:33-40. doi: 10.1007/s00421-007-0669-3

19. Joy JM, Lowery RP, Falcone PH, Mosman MM, Vogel RM, Carson $\mathrm{LR}$, et al. 28 days of creatine nitrate supplementation is apparently safe in healthy individuals. J Int Soc Sports Nutr. (2014) 11:60. doi: 10.1186/s12970-014-0060-9

20. Lobo DM, Tritto AC, da Silva LR, de Oliveira PB, Benatti FB, Roschel H, et al. Effects of long-term low-dose dietary creatine supplementation in older women. Exp Gerontol. (2015) 70:97-104. doi: 10.1016/j.exger.2015.07.012 
21. Mihic S, MacDonald JR, McKenzie S, Tarnopolsky MA. Acute creatine loading increases fat-free mass, but does not affect blood pressure, plasma creatinine, or CK activity in men and women. Med Sci Sports Exer. (2000) 32:291-6. doi: 10.1097/00005768-200002000-00007

22. Neves M, Jr, Gualano B, Roschel H, Lima FR, Lucia de Sa-Pinto A, Seguro $\mathrm{AC}$, et al. Effect of creatine supplementation on measured glomerular filtration rate in postmenopausal women. Appl Physiol Nutr Metab. (2011) 36:419-22. doi: 10.1139/h11-014

23. Ropero-Miller JD, Paget-Wilkes H, Doering PL, Goldberger BA. Effect of oral creatine supplementation on random urine creatinine, $\mathrm{pH}$, and specific gravity measurements. Clin Chem. (2000) 46:295-7.

24. Persky AM, Rawson ES. Safety of creatine supplementation. Sub-Cell Biochem. (2007) 46:275-89. doi: 10.1007/978-1-4020-6486-9_14

25. Poortmans JR, Auquier H, Renaut V, Durussel A, Saugy M, Brisson GR. Effect of short-term creatine supplementation on renal responses in men. Eur J Appl Physiol Occup Physiol. (1997) 76:566-7.

26. Bender A, Samtleben W, Elstner M, Klopstock T. Long-term creatine supplementation is safe in aged patients with Parkinson disease. Nutr Res. (2008) 28:172-8. doi: 10.1016/j.nutres.2008.01.001

27. Gualano B, de Salles Painelli V, Roschel H, Lugaresi R, Dorea E, Artioli GG, et al. Creatine supplementation does not impair kidney function in type 2 diabetic patients: a randomized, double-blind, placebo-controlled, clinical trial. Eur J Appl Physiol. (2011) 111:749-56. doi: 10.1007/s00421-0101676-3

28. Solis MY, Hayashi AP, Artioli GG, Roschel H, Sapienza MT, Otaduy MC, et al. Efficacy and safety of creatine supplementation in juvenile dermatomyositis: a randomized, double-blind, placebo-controlled crossover trial. Muscle Nerve (2016) 53:58-66. doi: 10.1002/mus.24681.

29. Vannas-Sulonen K, Sipila I, Vannas A, Simell O, Rapola J. Gyrate atrophy of the choroid and retina. A five-year follow-up of creatine supplementation. Ophthalmology (1985) 92:1719-27.

30. Pereira RTdS, Dörr FA, Pinto E, Solis MY, Artioli GG, Fernandes $\mathrm{AL}$, et al. Can creatine supplementation form carcinogenic heterocyclic amines in humans? J Physiol. (2015) 593:3959-71. doi: 10.1113/JP2 70861

31. Armentano MJ, Brenner AK, Hedman TL, Solomon ZT, Chavez J, Kemper GB, et al. The effect and safety of short-term creatine supplementation on performance of push-ups. Military Med. (2007) 172:312-7. doi: 10.7205/MILMED.172.3.312

32. Galvan E, Walker DK, Simbo SY, Dalton R, Levers K, O'Connor A, et al. Acute and chronic safety and efficacy of dose dependent creatine nitrate supplementation and exercise performance. J Int Soc Sports Nutr. (2016) 13:12. doi: 10.1186/s12970-016-0124-0

33. Lugaresi R, Leme M, de Salles Painelli V, Murai IH, Roschel H, Sapienza MT, et al. Does long-term creatine supplementation impair kidney function in resistance-trained individuals consuming a high-protein diet? J Int Soc Sports Nutr. (2013) 10:26. doi: 10.1186/1550-2783-10-26

34. Robinson TM, Sewell DA, Casey A, Steenge G, Greenhaff PL. Dietary creatine supplementation does not affect some haematological indices, or indices of muscle damage and hepatic and renal function. Br J Sports Med. (2000) 34:284-8. doi: 10.1136/bjsm.34.4.284

35. Groeneveld GJ, Beijer C, Veldink JH, Kalmijn S, Wokke JH, van den Berg LH. Few adverse effects of long-term creatine supplementation in a placebo-controlled trial. Int J Sports Med. (2005) 26:307-13. doi: 10.1055/s-2004-817917

36. Bemben MG, Lamont HS. Creatine supplementation and exercise performance: recent findings. Sports Med. (2005) 352:107-25. doi: 10.2165/00007256-200535020-00002

37. Kreider RB. Effects of creatine supplementation on performance and training adaptations. Mol Cell Biochem. (2003) 244:89-94. doi: 10.1023/A:1022469320296

38. Lanhers C, Pereira B, Naughton G, Trousselard M, Lesage FX, Dutheil F. Creatine Supplementation and lower limb strength performance: a systematic review and meta-analyses. Sports Med. (2015) 45:1285-94. doi: 10.1007/s40279-015-0337-4

39. Butts J, Jacobs B, Silvis M. Creatine Use in Sports. Sports Health (2017) 101:31-4. doi: 10.1177/1941738117737248
40. Cooper R, Naclerio F, Allgrove J, Jimenez A. Creatine supplementation with specific view to exercise/sports performance: an update. J Int Soc Sports Nutr. (2012) 9:33. doi: 10.1186/1550-2783-9-33.

41. Branch JD. Effect of creatine supplementation on body composition and performance: a meta-analysis. Int J Sport Nutr Exerc Metab. (2003) 132:198226. doi: 10.1123/ijsnem.13.2.198

42. Rawson ES, Volek JS. Effects of creatine supplementation and resistance training on muscle strength and weightlifting performance. J Strength Cond Res. (2003) 17:822-31. doi: 10.1519/00124278-200311000-00031

43. Volek JS, Duncan ND, Mazzetti SA, Staron RS, Putukian M, Gomez $\mathrm{AL}$, et al. Performance and muscle fiber adaptations to creatine supplementation and heavy resistance training. Med Sci Sports Exer. (1999) 31:1147-56.

44. Cornish SM, Chilibeck PD, Burke DG. The effect of creatine monohydrate supplementation on sprint skating in ice-hockey players. J Sports Med Phys Fitness (2006) 46:90-8.

45. Dawson B, Vladich T, Blanksby BA. Effects of 4 weeks of creatine supplementation in junior swimmers on freestyle sprint and swim bench performance. J Strength Cond Res. (2002) 16:485-90. doi: 10.1519/00124278-200211000-00001

46. Grindstaff PD, Kreider R, Bishop R, Wilson M, Wood L, Alexander C, et al. Effects of creatine supplementation on repetitive sprint performance and body composition in competitive swimmers. Int J Sport Nutr. (1997) 7:330-46.

47. Juhasz I, Gyore I, Csende Z, Racz L, Tihanyi J. Creatine supplementation improves the anaerobic performance of elite junior fin swimmers. Acta Physiol Hung. (2009) 96:325-36. doi: 10.1556/APhysiol.96.2009.3.6

48. Silva AJ, Machado Reis V, Guidetti L, Bessone Alves F, Mota P, Freitas $J$, et al. Effect of creatine on swimming velocity, body composition and hydrodynamic variables. J Sports Med Phys Fitness (2007) 47:58-64.

49. Kreider RB, Ferreira M, Wilson M, Grindstaff P, Plisk S, Reinardy J, et al. Effects of creatine supplementation on body composition, strength, and sprint performance. Med Sci Sports Exer. (1998) 30:73-82.

50. Stone MH, Sanborn K, Smith LL, O’Bryant HS, Hoke T, Utter AC, et al. Effects of in-season (5 weeks) creatine and pyruvate supplementation on anaerobic performance and body composition in American football players. Int J Sport Nutr. (1999) 9:146-65.

51. Bemben MG, Bemben DA, Loftiss DD, Knehans AW. Creatine supplementation during resistance training in college football athletes. Med Sci Sports Exer. (2001) 33:1667-73. doi: 10.1097/00005768-20011000000009

52. Hoffman J, Ratamess N, Kang J, Mangine G, Faigenbaum A, Stout J. Effect of creatine and beta-alanine supplementation on performance and endocrine responses in strength/power athletes. Int J Sport Nutr Exerc Metab. (2006) 16:430-46. doi: 10.1123/ijsnem.16.4.430

53. Chilibeck PD, Magnus C, Anderson M. Effect of in-season creatine supplementation on body composition and performance in rugby union football players. Appl Physiol Nutr Metab. (2007) 32:1052-7. doi: 10.1139/h07-072

54. Claudino JG, Mezencio B, Amaral S, Zanetti V, Benatti F, Roschel H, et al. Creatine monohydrate supplementation on lower-limb muscle power in Brazilian elite soccer players. J Int Soc Sports Nutr. (2014) 11:32. doi: 10.1186/1550-2783-11-32

55. Kerksick CM, Rasmussen C, Lancaster S, Starks M, Smith P, Melton C, et al. Impact of differing protein sources and a creatine containing nutritional formula after 12 weeks of resistance training. Nutrition (2007) 23:647-56. doi: 10.1016/j.nut.2007.06.015.

56. Kerksick CM, Wilborn CD, Campbell WI, Harvey TM, Marcello BM, Roberts MD, et al. The effects of creatine monohydrate supplementation with and without $\mathrm{D}$-pinitol on resistance training adaptations. J strength Cond Res. (2009) 23:2673-82. doi: 10.1519/JSC.0b013e3181b 3e0de

57. Volek JS, Kraemer WJ, Bush JA, Boetes M, Incledon T, Clark KL, et al. Creatine supplementation enhances muscular performance during high-intensity resistance exercise. J Am Diet Assoc. (1997) 97:765-70. doi: 10.1016/s0002-8223(97)00189-2 
58. Volek JS, Mazzetti SA, Farquhar WB, Barnes BR, Gomez AL, Kraemer WJ. Physiological responses to short-term exercise in the heat after creatine loading. Med. Sci Sports Exer. (2001) 33:1101-8. doi: 10.1097/00005768-200107000-00006

59. Volek JS, Ratamess NA, Rubin MR, Gomez AL, French DN, McGuigan MM, et al. The effects of creatine supplementation on muscular performance and body composition responses to short-term resistance training overreaching. Eur J Appl Physiol. (2004) 91:628-37. doi: 10.1007/s00421-003-1031-z.

60. Buford TW, Kreider RB, Stout JR, Greenwood M, Campbell B, Spano $M$, et al. International Society of Sports Nutrition position stand: creatine supplementation and exercise. J Int Soc Sports Nutr. (2007) 4:6. doi: 10.1186/1550-2783-4-6

61. Tarnopolsky MA. Potential benefits of creatine monohydrate supplementation in the elderly. Curr Opin Clin Nutr Metab Care (2000) 3:497-502. doi: 10.1097/00075197-200011000-00013

62. Rawson ES, Venezia AC. Use of creatine in the elderly and evidence for effects on cognitive function in young and old. Amino acids (2011) 40:1349-62. doi: 10.1007/s00726-011-0855-9

63. Kreider RB, Wilborn CD, Taylor L, Campbell B, Almada AL, Collins R, et al. ISSN exercise \& sport nutrition review: research \& recommendations. J Int Soc Sports Nutr. (2010) 7:7. doi: 10.1186/1550-2783-7-7

64. Devries MC, Phillips SM. Creatine supplementation during resistance training in older adults-a meta-analysis. Med Sci Sports Exer. (2014) 46:1194203. doi: 10.1249/mss.0000000000000220

65. Wiroth JB, Bermon S, Andrei S, Dalloz E, Hebuterne X, Dolisi C. Effects of oral creatine supplementation on maximal pedalling performance in older adults. Eur J Appl Physiol. (2001) 84:533-9. doi: 10.1007/s004210000370

66. McMorris T, Mielcarz G, Harris RC, Swain JP, Howard A. Creatine supplementation and cognitive performance in elderly individuals. Neuropsychol Dev Cogn B Aging Neuropsychol Cogn. (2007) 14:517-28. doi: 10.1080/13825580600788100

67. Rawson ES, Clarkson PM. Acute creatine supplementation in older men. Int J Sports Med. (2000) 21:71-5. doi: 10.1055/s-2000-8859

68. Aguiar AF, Januario RS, Junior RP, Gerage AM, Pina FL, do Nascimento MA, et al. Long-term creatine supplementation improves muscular performance during resistance training in older women. Eur J Appl Physiol. (2013) 113:987-96. doi: 10.1007/s00421-012-2514-6

69. Smith J, Dahm DL. Creatine use among a select population of high school athletes. Mayo Clinic (2000) 75:1257-63. doi: 10.4065/75.12.1257.

70. Metzl JD, Small E, Levine SR, Gershel JC. Creatine use among young athletes. Pediatrics (2001) 108:421-5. doi: 10.1542/peds.108.2.421

71. Kayton S, Cullen RW, Memken JA, Rutter R. Supplement and ergogenic aid use by competitive male and female high school athletes. Med Sci Sports Exerc. (2002) 34:S193. doi: 10.1097/00005768-200205001-01087

72. O'Dea JA. Consumption of nutritional supplements among adolescents: usage and perceived benefits. Health Edu Res. (2003) 18:98-107. doi: 10.1093/her/18.1.98

73. Bell A, Dorsch KD, McCreary DR, Hovey R. A look at nutritional supplement use in adolescents. J Adolescent Health (2004) 34:508-16. doi: 10.1016/j.jadohealth.2003.07.024

74. Hoffman JR, Faigenbaum AD, Ratamess NA, Ross R, Kang J, Tenenbaum G. Nutritional supplementation and anabolic steroid use in adolescents. Med Sci Sports Exer. (2008) 40:15-24. doi: 10.1249/mss.0b013e31815a5181

75. Petroczi A, Naughton DP. The age-gender-status profile of high performing athletes in the UK taking nutritional supplements: lessons for the future. J Int Soc Sports Nutr. (2008) 5:2. doi: 10.1186/1550-2783-5-2

76. Diehl K, Thiel A, Zipfel S, Mayer J, Schnell A, Schneider S. Elite adolescent athletes' use of dietary supplements: characteristics, opinions, and sources of supply and information. Int J Sport Nutr Exerc Metab. (2012) 22:165-74. doi: $10.1123 /$ ijsnem.22.3.165

77. Evans MW, Jr, Ndetan H, Perko M, Williams R, Walker C. Dietary supplement use by children and adolescents in the United States to enhance sport performance: results of the National Health Interview Survey. $J$ Primary Prevent. (2012) 33:3-12. doi: 10.1007/s10935-012-0261-4

78. Kerksick CM, Fox E. Sports Nutrition Needs for Child and Adolescent Athletes. Boca Raton, FL: CRC Press (2016).

79. Maughan RJ, Burke LM, Dvorak J, Larson-Meyer DE, Peeling P, Phillips SM, et al. IOC consensus statement: dietary supplements and the high-performance athlete. Br J Sports Med. (2018) 52:439-55. doi: 10.1136/bjsports-2018-099027

80. Knapik JJ, Steelman RA, Hoedebecke SS, Austin KG, Farina EK, Lieberman HR. Prevalence of dietary supplement use by athletes: systematic review and meta-analysis. Sports Med. (2016) 46:103-23. doi: 10.1007/s40279-015-0387-7.

81. McGuine TA, Sullivan JC, Bernhardt DA. Creatine supplementation in Wisconsin high school athletes. WMJ (2002) 101:25-30.

82. Ziegler PJ, Nelson JA, Jonnalagadda SS. Use of dietary supplements by elite figure skaters. Int J Sport Nutr Exerc Metab. (2003) 13:266-76. doi: 10.1123/ijsnem.13.3.266

83. Braun H, Koehler K, Geyer H, Kleiner J, Mester J, Schanzer W. Dietary supplement use among elite young German athletes. Int J Sport Nutr Exerc Metab. (2009) 19:97-109. doi: 10.1123/ijsnem.19.1.97

84. Mohebbi H, Rahnama N, Moghadassi M, Ranjbar K. Effect of creatine supplementation on sprint and skill performance in Young Soccer Players. Middle-East J Sci Res. (2012) 12:397-401.

85. Ostojic SM. Creatine supplementation in young soccer players. Int J Sport Nutr Exerc Metab. (2004) 14:95-103. doi: 10.1123/ijsnem.14.1.95

86. Yanez-Silva A, Buzzachera CF, Picarro IDC, Januario RSB, Ferreira LHB, McAnulty SR, et al. Effect of low dose, short-term creatine supplementation on muscle power output in elite youth soccer players. J Int Soc Sports Nutr. (2017) 14:5. doi: 10.1186/s12970-017-0162-2

87. Theodorou AS, Cooke CB, King RFGJ, Hood C, Denison T, Wainwright BG, et al. The effect of longer-term creatine supplementation on elite swimming performance after an acute creatine loading. J Sports Sci. (1999) 17:853-9. doi: 10.1080/026404199365416.

88. Unnithan VB, Veehof SH, Vella CA, Kern M. Is there a physiologic basis for creatine use in children and adolescents? J Strength Cond Res. (2001) 15:524-8. doi: 10.1519/00124278-200111000-00021

89. Merege-Filho CA, Otaduy MC, de Sa-Pinto AL, de Oliveira MO, de Souza Goncalves L, Hayashi AP, et al. Does brain creatine content rely on exogenous creatine in healthy youth? a proof-of-principle study. Appl Physiol Nutr Metab. (2017) 42:128-34. doi: 10.1139/apnm-2016-0406

90. Solis MY, Artioli GG, Otaduy MCG, Leite CDC, Arruda W, Veiga $\mathrm{RR}$, et al. Effect of age, diet, and tissue type on $\mathrm{PCr}$ response to creatine supplementation. J Appl Physiol. (2017) 123:407-14. doi: 10.1152/japplphysiol.00248.2017

91. Braissant O, Henry H, Beard E, Uldry J. Creatine deficiency syndromes and the importance of creatine synthesis in the brain. Amino acids (2011) 40:1315-24. doi: 10.1007/s00726-011-0852-z

92. Sykut-Cegielska J, Gradowska W, Mercimek-Mahmutoglu S, StocklerIpsiroglu S. Biochemical and clinical characteristics of creatine deficiency syndromes. Acta Biochim Pol. (2004) 514:875-82.

93. Stockler-Ipsiroglu S, van Karnebeek CD. Cerebral creatine deficiencies: a group of treatable intellectual developmental disorders. Semin Neurol. (2014) 34:350-6. doi: 10.1055/s-0034-1386772.

94. Battini R, Alessandri MG, Leuzzi V, Moro F, Tosetti M, Bianchi MC, et al. Arginine:glycine amidinotransferase (AGAT) deficiency in a newborn: early treatment can prevent phenotypic expression of the disease. J Pediatr. (2006) 1486:828-30. doi: 10.1016/j.jpeds.2006.01.043

95. Stockler-Ipsiroglu S, van Karnebeek C, Longo N, Korenke GC, MercimekMahmutoglu S, Marquart I, et al. Guanidinoacetate methyltransferase (GAMT) deficiency: outcomes in 48 individuals and recommendations for diagnosis, treatment and monitoring. Mol Genet Metab. (2014) 111:16-25. doi: 10.1016/j.ymgme.2013.10.018

96. Tarnopolsky MA, Mahoney DJ, Vajsar J, Rodriguez C, Doherty TJ, Roy $\mathrm{BD}$, et al. Creatine monohydrate enhances strength and body composition in Duchenne muscular dystrophy. Neurology (2004) 62:1771-7. doi: 10.1212/01.WNL.0000125178.18862.9D

97. Louis M, Lebacq J, Poortmans JR, Belpaire-Dethiou MC, Devogelaer JP, Van Hecke P, et al. Beneficial effects of creatine supplementation in dystrophic patients. Muscle Nerve (2003) 27:604-10. doi: 10.1002/mus.10355

98. Escolar DM, Buyse G, Henricson E, Leshner R, Florence J, Mayhew J, et al. CINRG randomized controlled trial of creatine and glutamine in Duchenne muscular dystrophy. Ann Neurol. (2005) 58:151-5. doi: 10.1002/ana.20523

99. Hayashi AP, Solis MY, Sapienza MT, Otaduy MC, de Sa Pinto AL, Silva CA, et al. Efficacy and safety of creatine supplementation in 
childhood-onset systemic lupus erythematosus: a randomized, doubleblind, placebo-controlled, crossover trial. Lupus (2014) 23:1500-11. doi: $10.1177 / 0961203314546017$

100. Greydanus DE, Patel DR. Sports doping in the adolescent: the Faustian conundrum of Hors de Combat. Pediatr Clin North Am. (2010) 57:729-50. doi: 10.1016/j.pcl.2010.02.008

101. Ranby KW, Aiken LS, MacKinnon DP, Elliot DL, Moe EL, McGinnis W, et al. A Mediation analysis of the ATHENA intervention for female athletes: prevention of athletic-enhancing substance use and unhealthy weight loss behaviors. J Pediatr Psychol. (2009) 34:1069-83. doi: 10.1093/jpepsy/ jsp025
Conflict of Interest Statement: The authors declare that the research was conducted in the absence of any commercial or financial relationships that could be construed as a potential conflict of interest.

Copyright (c) 2018 Jagim, Stecker, Harty, Erickson and Kerksick. This is an openaccess article distributed under the terms of the Creative Commons Attribution License (CC BY). The use, distribution or reproduction in other forums is permitted, provided the original author(s) and the copyright owner(s) are credited and that the original publication in this journal is cited, in accordance with accepted academic practice. No use, distribution or reproduction is permitted which does not comply with these terms. 